\title{
THE EFFECT OF CHEMICAL AND NON-CHEMICAL CONTROL METHODS ON WEEDS IN POTATO (SOLANUM TUBEROSUM L.) CULTIVATION IN ARDABIL PROVINCE, IRAN
}

\author{
AZADBAKHT, A. ${ }^{1}-$ Alebrahim, M. T. ${ }^{1 *}-$ GhaVidel, A. ${ }^{2}$ \\ ${ }^{I}$ Faculty of Agriculture and Natural Resources, Department of Agronomy and Plant Breeding \\ University of Mohaghegh Ardabili, Ardabil, Iran \\ e-mail: afsharazadbakht@uma.ac.ir; phone: +98-938-002-7313 \\ ${ }^{2}$ Faculty of Agriculture and Natural Resources, Department of Soil Science and Engineering \\ University of Mohaghegh Ardabili, Ardabil, Iran \\ e-mail: ghavidel@uma.ac.ir; phone: +98-912-608-4121 \\ *Corresponding author \\ e-mail: m_ebrahim@uma.ac.ir; phone: +98-912-350-1493 \\ (Received $1^{\text {st }}$ May 2017; accepted 25 $5^{\text {th }}$ Jul 2017)
}

\begin{abstract}
Potato is one of the most important crops in Iran and on average, this crop is affected annually by weeds damage which must be prevented by various control methods. Crop residues and other types of mulches are non-chemical methods of weed control in sustainable agricultural systems. The aim of present study was to investigate the effect of chemical and non-chemical control methods on weeds in potato crop. An experiment was conducted in 2015 in two agricultural research stations of Alarogh and Samian in Ardabil city in a randomized complete block design with three replications. The treatments were as follows: 1) Trifluralin herbicide, 2) Metribuzin herbicide, 3) cultivator, 4) wheat straw mulch, 5) canola straw mulch, 6) black plastic mulch, 7) transparent plastic mulch 8) weed infested and 9) weed free. Based on results, all treatments were affected by weed control methods $(\mathrm{P} \leq 0.01)$, so that Shannon-Wiener index treatment was $(\mathrm{P} \leq 0.05)$. The greatest diversity of Shannon-Wiener index measured in present experiment was observed in weed infested treatment (average comparison by Duncan test). The treatments of Trifluralin herbicide, cultivator and transparent plastic mulch after the weed infested treatment had the highest species diversity. The lowest density of weeds was related to the wheat straw mulch. Most weeds density was counted as $99.1 \mathrm{plants} / \mathrm{m}^{2}$ of weed infested treatment. The wheat straw mulch deceased weeds density as $84 \%$ compared to weed infested. The canola straw mulch also was deceased weeds density as $79 \%$ comparing to weed infested. However, weed biomass in the treatments of transparent and black plastic mulch compared to the weed infested treatment had the highest weeds biomass as 48 and $40 \%$, respectively. The lowest weed biomass was observed in canola and wheat mulch by 16 and $18 \%$ after the weed infested. It can be conducted that, the use of plant mulches or residues can provide more proper control of weeds compared to the use of herbicide and the use of plant mulches reduces use of herbicides.
\end{abstract}

Keywords: biomass, canola, density, diversity, herbicide, plant mulch, plastic mulch, wheat

\section{Introduction}

In most potato producer countries in the world such as China, India, Russia, Ukraine, America, Germany, Bangladesh, etc. with different climatic conditions, weed control is carried out by agricultural, mechanical and chemical methods or their combination in potato fields. (Hutchinson et al., 2011; Kunz et al., 2015; Weber et al., 2016). Metribuzin (Sencor) is an herbicide belonging to Triazine family that is used in potato fields both 
before planting and pre-emergence potato, mostly to control annual grass and broad leaf weeds (Zand et al., 2007; Zaki et al., 2014). The use of Trifluralin (Treflan) is effective as pre- emergence in hilling step to control weeds of potato crop (Sheikhi et al., 2012; Borzouei et al., 2013). The use of tillage or cultivator along with herbicide, control of weeds effectively and it is used as one of the major methods of weed control in potato crop (Mohammaddoust et al., 2011). Nowadays, an organic method that is used in weed management is the application of mulches. Moreover, the application of herbal residues or plant mulch has a great importance to develop and expand sustainable farming systems. The need to increase farm productivity and profitability is a factor that stimulates the development of methods based on the ecological management of weeds. Considering that in industrialized countries as well as developing countries, increasing the inputs cost has been more than the products cost, so that has been endangered the economic support for farmers. If the better ecological process is used in weed management, agricultural income will be increased by reducing the inputs cost and this topic helping farmers to provide market friendly agricultural products (Dejam et al., 2010; Jafari et al., 2013; Najafi et al., 2016). Specifically, when using a weed control method, the competition of weeds with crop plants is reduced and as a result the use of other methods (as chemical control) to weed control is reduced. The purpose of this experiment was to determinate the best method that prevents weed growth and competition of weeds with crop.

\section{Materials and Methods}

\section{Study area}

The present experiment was conducted in 2015 at two stations: 1. Alarogh Agricultural Research Stationin (Fig. 1) Ardabil Province, Iran with an altitude of 1350 meters above sea level, a longitude of $48^{\circ}, 20^{\prime}$, a latitude of $38^{\circ}, 15^{\prime}$, a semi-arid and cold climate, and a soil pH of 7.6, and 2. Samian Agricultural Research Station (Fig. 1) in Ardabil Province, Iran with an altitude of 1320 meters above sea level, a longitude of $48^{\circ}, 15^{\prime}$, a latitude of $38^{\circ}, 23$ ', a semi-arid and cold climate, and a soil $\mathrm{pH}$ of 7.5-8. Two areas of Alarogh and Samian in Ardabil province are major areas under potato cultivation and many researches are being made on potato crop in these areas. Laboratory measurements were performed at the faculty of agricultural sciences and natural resources, university of Mohaghegh Ardabili, Ardabil, Iran.

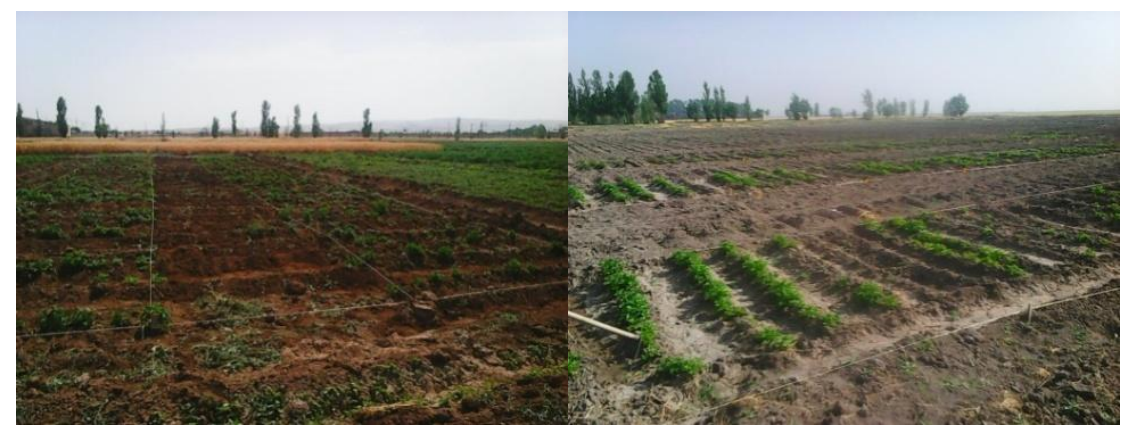

Figure 1. The images of the farm stations in Alarogh (Left) and Samian (Right) 


\section{Experimental design and treatments}

The present study employed a randomized complete block design with three replications. The treatments were as follows: 1) Spraying Trifluralin herbicide on the soil between the rows of potato plants $(75 \% \mathrm{EC}$ was formulated with the amount of $2 \mathrm{~L} / \mathrm{ha}$ by the Matabi model with an 8001 nozzle and the constant speed and pressure of sprayer in all treatments based on the $250 \mathrm{~L} /$ ha spraying; thus, the Trifluralin was mixed with soil at the depth of $0-10 \mathrm{~cm}$ ) immediately after the second hilling of potato plants 45 days after planting the potatoes. 2) Spraying Metribuzin herbicide on the soil between the rows of potato plants with the amount of $1000 \mathrm{~g} / \mathrm{ha}$ (with the formulation of $70 \% \mathrm{WP}$ and sprayer specification such as the sprayer used for Trifluralin herbicides) immediately after the second soil hilling of potato plants 45 days after planting the potatoes. 3) Cultivator practice once for 20 days after the second hilling of potato plants 65 days after planting the potatoes. 4) Wheat straw mulch with the amount of 5 ton/ha and thickness of $15 \mathrm{~cm}$ immediately after the second soil hilling of potato plants 45 days after planting the potatoes. 5) Canola straw mulch applied similar to WH treatment. 6) The application of black plastic mulch, covering the space between the rows with plastic sheets with the thickness of 50 microns immediately after the second soil hilling of potato plants 45 days after planting the potatoes in the plot or row. 7) The application of transparent plastic mulch was similar to that of BPL treatment. 8) Weed infested or no weed removal in the entire growing season. 9) Weed free or weed removal in the entire growing season in both stations.

\section{Land preparation and planting}

The land was prepared for planting by secondary plowing immediately after favorable weather and soil conditions. On $5^{\text {th }}$ June 2015, potato tubers (a variety of Agria) were handplanted in rows, between which there was a distance of $75 \mathrm{~cm}$ and a distance of $25 \mathrm{~cm}$ on the ridge (the distance between the tubers planted on the planting row in each plot). Each plot had an area of $3 \times 3.5 \mathrm{~m}$.

After selecting the locations of experiment and before the preparation actions, 10 points of each farm soil were randomly sampled to provide composite samples and to analyze soil. Then, based on the results of soil analysis, fertilization was performed with application of phosphate fertilizers (Triple superphosphate with amount of $178 \mathrm{~kg} \cdot \mathrm{ha}^{-1}$ at two steps based on recommendation of research stations, 50 percent at planting time and 50 percent during the formation of tubers) and nitrogen (urea with amount of $300 \mathrm{~kg} \cdot \mathrm{ha}^{-1}$ at three times, 25 percent during potato planting, 50 percent during emergence and 25 percent immediately after formation of tubers). Irrigation was also conducted after the first step of soil irrigation and emergence of plants with a 7-day interval. Two potato hilling steps were done for at the base of plants using a hoe at 25 and 45 days after potato planting, respectively.

\section{Potato and weed sampling}

At the end of the growing season and a month before harvesting potato tubers (September), the weeds were sampled according to species and were counted. Weed sampling were performed in each plot with dimensions of $0.5 \times 0.75$ square $\mathrm{cm}$ of the soil surface and were transported to the laboratory. After counting the number of plants by 
species, shoots of weed of each species were separately and put in special bags and placed at oven for 72 hours at $75 \circ \mathrm{C}$ and after drying completely, its were weighed with a balance with precision of $0.001 \mathrm{~g}$. Before performing statistical analysis and for data uniformity, conversion of $\sqrt{x}+0.5$ was used for data related to density and dried weight of weed. In order to determine the potato yield, after completion of the growing season and ripening potato tubers, the middle two rows of plants (inside plots) were collected during a meter entirely.

\section{Shannon-Wiener index}

In order to estimate weed species diversity, Shannon-Wiener index were used. ShannonWiener index was used to calculate the following equation:

$$
H^{\prime}=-\Sigma\left(n_{i} / N\right)\left(\log _{2} n_{i} / N\right)
$$

In the mentioned equation, $H^{\prime}$ is Shannon-Wiener index, $\left(0 \leq \mathrm{H}^{\prime}\right), n_{i}$ is the number of $i$ th species and $\mathrm{N}$ is the number of peoples (Shannon and Wiener, 1949). The data analysis was finally performed using SAS ver. 9.1 software and graphs were drawn by Excel ver. 2013 software.

\section{Results and Discussion}

\section{Weed species diversity and density}

In this study, among the 12 weeds species observed in potato field were the seven species annual weeds and five species perennial weeds. The weed species were include Common Amaranth, lamb's quarters, Bindweed, Green foxtail, Prickly lettuce, Russian knapweed and Milk thistle had the highest weed prevalence of dominant (Table 1).

Table 1. The biological and Photosynthetic traits of weed species observed in the sampling units of potato farm

\begin{tabular}{|c|c|c|c|c|c|}
\hline row & Species name & Scientific name & Family & Life cycle & $\begin{array}{c}\text { Photosynthetic } \\
\text { cycle }\end{array}$ \\
\hline 1 & Comon Amaranth & $\begin{array}{l}\text { Amaranthus } \\
\text { retroflexus }\end{array}$ & Amaranthaceae & Annual & $\mathrm{C} 4$ \\
\hline 2 & Russian knapweed & Acroptilon repens & Asteraceae & Perennial & C3 \\
\hline 3 & creeping thistle & Cirsium arvense & Asteraceae & Perennial & C3 \\
\hline 4 & Prickly lettuce & Lactuca seriola & Asteraceae & Annual & C3 \\
\hline 5 & Wild mustard & Sinapis arvensis & Brassicaceae & Annual & C3 \\
\hline 6 & $\begin{array}{c}\text { Common Lamb's } \\
\text { Quarters }\end{array}$ & Chenopodium album & Chenopodiaceae & Annual & $\mathrm{C} 3$ \\
\hline 7 & Bindweed & Convolvulus arvensis & Convolvulaceae & Perennial & $\mathrm{C} 3$ \\
\hline 8 & Pigweed & $\begin{array}{l}\text { Echinochloa crus } \\
\text { galli }\end{array}$ & Poaceae & Annual & $\mathrm{C} 4$ \\
\hline
\end{tabular}




\begin{tabular}{c|c|c|c|c|c}
9 & Green foxtail & Setaria viridis & Poaceae & Annual & C3 \\
10 & Licorice & Glycyrrhiza glabra & Papilionaceae & Perennial & C3 \\
11 & Tumbleweed & Salsola kali & Chenopodiaceae & Annual & CAM \\
12 & Milk thistle & Sonchus arvensis & Asteraceae & Perennial & C3 \\
\hline
\end{tabular}

In present study the average of Shannon-Wiener diversity index in both stations was changed $(\mathrm{P} \leq 0.05)$ by changing of management practices for weed management (Table 2 and Fig. 2). The greatest diversity of Shannon-Wiener index measured in present experiment was observed in weed infested treatment (Fig. 2). Blackwell (2011) stated that failure to weeds control in arable land or fallow cause of increase the density of weeds and also can be effective on weeds species diversity. According to the Shannon-Wiener index the treatments of Trifluralin, cultivators and transparent plastic mulch after the weed infested treatment had the highest species diversity (Fig. 2). The light passes through transparent plastic mulch and is likely to stimulate the germination of weeds but because of the low temperature in present region (Experiment locations) could not prevent weeds germination and the result, may be stimulated weed species seeds and causes of weed germination in the amplitude and so may be effective on the composition and diversity of weeds. Majd et al. (2014) also achieved to similar results in this regard.

Table 2. Combined statistical analysis (ANOVA) of the effects of experimental treatments on weeds biomass, density and Shannon -Wiener diversity index in potato cultivation

Mean of squares (MS)

\begin{tabular}{c|c|c|c|c|c|c|c|c}
\hline & & \multicolumn{3}{|c|}{ Weed biomass } & \multicolumn{3}{c}{ Weed density } & \\
\hline (S.O.V) & Df & Total & Grass & $\begin{array}{c}\text { Broad } \\
\text { leaf }\end{array}$ & Total & Grass & $\begin{array}{c}\text { Broad } \\
\text { leaf }\end{array}$ & $\begin{array}{c}\text { Shannon- } \\
\text { Wiener } \\
\text { index }\end{array}$ \\
\hline Station & 1 & $3.3^{\text {ns }}$ & $3.9^{\text {ns }}$ & $9.6^{\text {ns }}$ & $1.5^{\text {ns }}$ & $4.5^{\text {ns }}$ & $9.6^{\text {ns }}$ & $0.4^{\text {ns }}$ \\
Rep (Station) & 4 & 22.2 & 1.1 & 24.8 & 2.3 & 0.5 & 24.8 & 0.03 \\
Treatment & 7 & $56.1^{* *}$ & $7.9^{* *}$ & $56.9^{* *}$ & $21.3^{* *}$ & $8.0^{* *}$ & $56.9^{* *}$ & $0.3^{*}$ \\
Station $\times$ Treat & 7 & $5.1^{\text {ns }}$ & $1.3^{\text {ns }}$ & $5.4^{\text {ns }}$ & $0.8^{\text {ns }}$ & $1.1^{\text {ns }}$ & $5.4^{\text {ns }}$ & $0.1^{\text {ns }}$ \\
Error & 28 & 8.5 & 1.8 & 9.8 & 1.4 & 1.5 & 9.8 & 0.1 \\
CV & - & 30.6 & 52.1 & 34.6 & 20.1 & 49.1 & 34.6 & 31.7 \\
\hline
\end{tabular}

ns, non-significant difference. **, difference in level 1 percent. *, difference in level 0.5 percent.

In the farms, the composition, diversity and species richness simultaneously is affected by many factors including climate, soil properties, agricultural products, agricultural operations, tillage, cultivator and farming characteristics (Lososova et al., 2008; Azad et al., 
2015). The lowest weed species diversity based on Shannon-Wiener index similarly were related to treatments of canola straw mulch, Metribuzin herbicide and black plastic mulch (Fig. 2). One reason for the decline of species diversity as a result of the use of mulch, is reducing amount of light reached into weed canopy, because increasing the coverage layer of mulch, more percent of light absorbed by crops or by mulch and therefore the remaining amount of light is reduced to weeds consumption as a result of reduced weed density and diversity (Dvorak et al., 2012; Azad et al., 2015).

Table 3. Combined statistical analysis (ANOVA) of the effects of experimental treatments on tuber yield of potato

\begin{tabular}{c|c|c}
\hline & & Mean of squares (MS) \\
\cline { 3 - 3 } (S.O.V) & Df & Potato tuber yield \\
\hline Station & 1 & $4.5^{\mathrm{ns}}$ \\
Rep (Station) & 4 & 0.5 \\
Treatments & 8 & $8.0^{* *}$ \\
Station $\times$ Treat & 8 & $1.1^{\mathrm{ns}}$ \\
Error & 32 & \\
CV & &
\end{tabular}

ns, non significant difference ${ }^{* *}$, difference in level 1 percent.

Brassica plant debris in addition to preventing light from reaching weed seeds and prevent the germination of weed spectrum like some monocots may reduce the species diversity also Allelochemicals released by the organs of these plants (Brassicas) may be effective on weed species composition (Pawlonka et al. 2015). The use of herbicides as a result of a specific range of weed control can be reduced weed diversity (Channappaguar et al., 2007; Nikolic et al., 2013). Based on results obtained from the combined statistical analysis of traits in present study, the treatments had a significant effect $(\mathrm{P} \leq 0.01)$ on weeds density in both stations (Table 2) so that the lowest total weeds density was obtained in wheat straw mulch and then, Metribuzin herbicide. The maximum total weeds density was counted as 99.1 plants per square meter in the weed infested treatment and the lowest total weeds density were related to the wheat straw mulch as 15.5 plants per square meter (Fig. 3).

The results showed that the use of wheat straw mulch decreased total weed density by about $84 \%$ comparing to weed infested treatment (Fig. 3). Canola straw mulch also decreased total weed density comparing to weed infested treatment by about $79 \%$ so that weed density difference in canola straw mulch compared to weed infested treatment was significant at $(\mathrm{P} \leq 0.01)$ (Table 2$)$, however in terms of reducing the number of weeds it was less successful than wheat straw mulch, although this difference between two mentioned treatment was not significant (Fig. 3). Weed density reduction in plots where herbal mulch were used, may be because of inhibition of weed germination and growth at this stage of potato growth or as result of the release of Allelopathic substance, the results of the research of many researchers (Dhima et al., 2006; Judice et al., 2007) also showed that plant mulches prevent weed germination or growth with preventing the penetration of light or the release of Allelopathic substances. 




Weed management treatments

Figure 2. The effect of different weed management treatments application on Shannon-Wiener diversity index in potato cultivation (The averages of at least one similar letter are not significantly different at $(\mathrm{P} \leq 0.05)$, using Duncan's multiple range test)

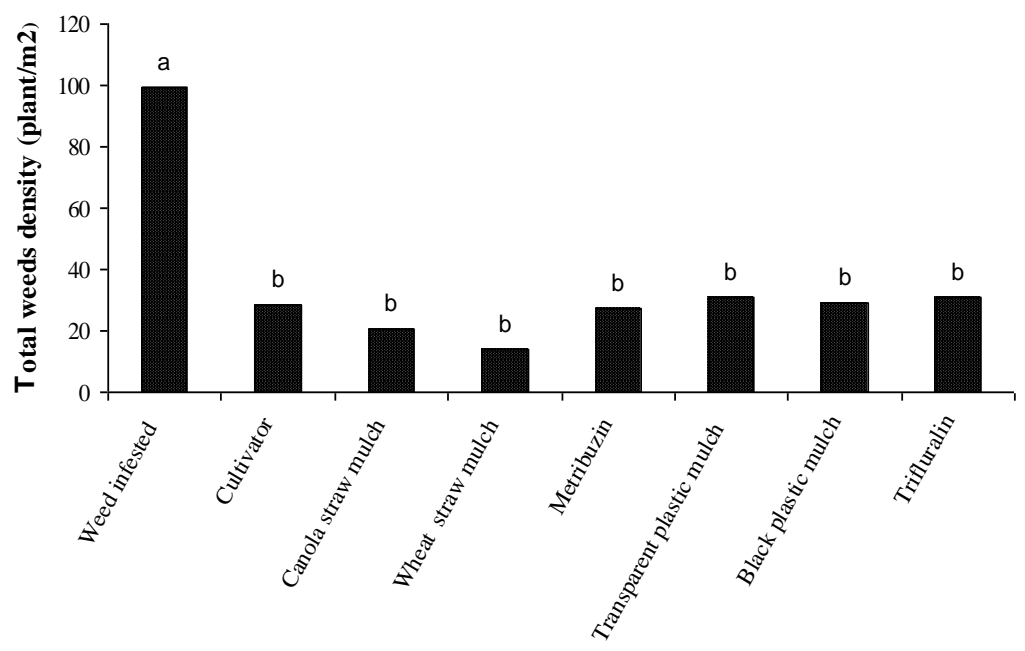

Weed management treatments

Figure 3. The effect of different weed management treatments on total weed density average $\left(\right.$ plant $\left./ \mathrm{m}^{2}\right)$ in potato cultivation (The averages of at least one similar letter are not significantly different at $(\mathrm{P} \leq 0.05)$, using Duncan's multiple range test) 


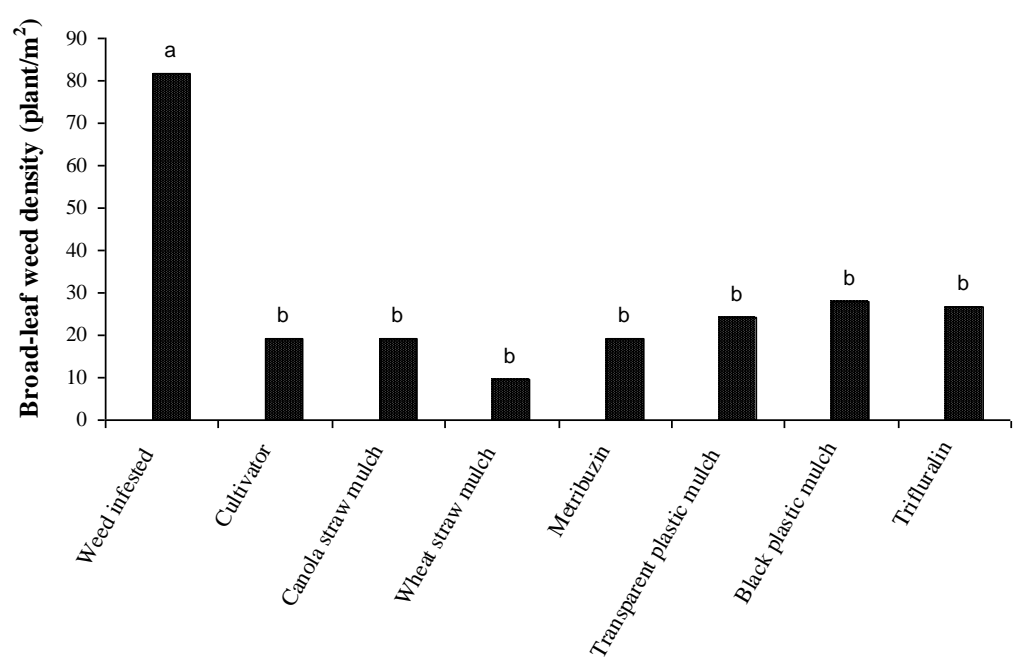

Weed management treatments

Figure 4. The effect of different weed management treatments on Broad-leaf weeds density average $\left(\mathrm{plant} / \mathrm{m}^{2}\right)$ in potato cultivation (The averages of at least one similar letter are not significantly different at $(\mathrm{P} \leq 0.05)$, using Duncan's multiple range test $)$

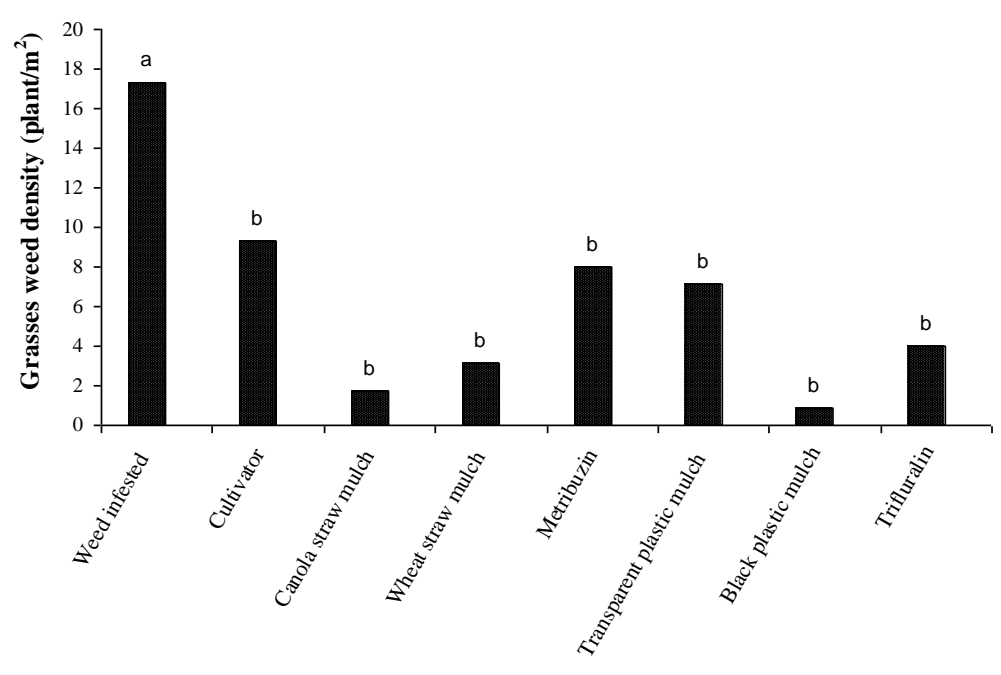

Weed management treatments

Figure 5. The effect of different weed management treatments on Grass weeds density average $\left(\right.$ plant $\left./ \mathrm{m}^{2}\right)$ in potato cultivation (The averages of at least one similar letter are not significantly different at $(\mathrm{P} \leq 0.05)$, using Duncan's multiple range test $)$

Moreover, Dhima et al. (2006) reported when applying the straw mulch of barley, Triticale and Rye in sugar beet crop, the germination of Pigweed (Echinochloa crus galli), were $69 \%$ less than the plots without plant residues. Herbicides had also a significant impact at $(\mathrm{P} \leq 0.01)$ on weeds density of potato cultivation (Table 2). Figure 3 shows that total weed density was lower in Metribuzin and Trifluralin treatments compared to the 
weed infested treatment. At Metribuzin and Trifluralin treatments, total weed density was less than the weed infested treatment as 72 and 69\%, respectively. Hence these differences were significant at $(\mathrm{P} \leq 0.01)$ (Table 2). Although the Metribuzin herbicide after wheat straw mulch had the greatest impact in reducing weed density of potato crop and showed a better performance than the Trifluralin herbicides to prevent from germination and growth of weed during the cultivation period, it had no significant differences with mentioned treatments in terms of reducing weed density. Channappaguar et al. (2007) showed among the herbicides of Alachlor, Pendimethalin, Diuron and Metribuzin, the Metribuzin had maximum efficiency in controlling broadleaf and grass weeds of potato crop because this herbicide effectively prevents of weeds germination and so control weeds. Black and transparent plastic mulch significantly controlled total weed density, the black color of plastic prevents reaching full light to light-dependent weeds for their germination and this point indicates the inhibitory effect of black plastic on the germination and growth of weeds (Majd et al., 2014). Density of broadleaf weeds species, as most important weeds in potato cultivator in all mulch treatments, cultivator and herbicides was reduced compared to weed infested treatment (Fig. 4). The maximum density of Comon Amaranth (broadleaf weed specie) has been observed in treatments of black plastic mulch, Trifluralin and transparent plastic mulch, hence the lowest density was observed in treatments of wheat straw mulch and Metribuzin herbicides application (Fig. 4). The black plastic mulch in some cases during the growing season is decomposed by sunlight and it may not completely effective to prevent of weed germination as a result of irrigation, wind and other factors, and gives the growth and germination opportunities to weed seeds (Haidar and Sidahmed, 2000; Majd et al., 2014; Zhang et al., 2015). Lamb's quarters weed (broadleaf weed specie) had the highest density in the application of herbicides of Metribuzin and transparent plastic mulch and the minimum density in treatments of cultivator and wheat straw mulch (Fig. 4). The use of Poaceae residues as mulch is one of the ecological agriculture components that well prevents of weed seeds germination (Maldonado et al. 2001; Shiyam et al., 2011; Didon et al., 2014). In present experiment the highest grass weed density was related to the treatment of cultivator, however the least one was related to the treatments of black plastic mulch, canola straw mulch and wheat straw mulch (Fig. 5). Various experiments have shown that different treatments such as herbicides and plant residues affecting on weed species composition in different ways (Dhima et al., 2006). However in the present study, density of broadleaf weeds was more than grass weeds, in other words, the highest density of weeds was related to the broadleaf weeds. Moreover, all treatments could significantly reduce the level of broadleaf and grass weeds compared to weed infested treatment.

\section{Weed biomass}

The results of experiment showed that the use of herbicides had a significant effect on the weeds biomass at $(\mathrm{P} \leq 0.01)$ (Table 2). 


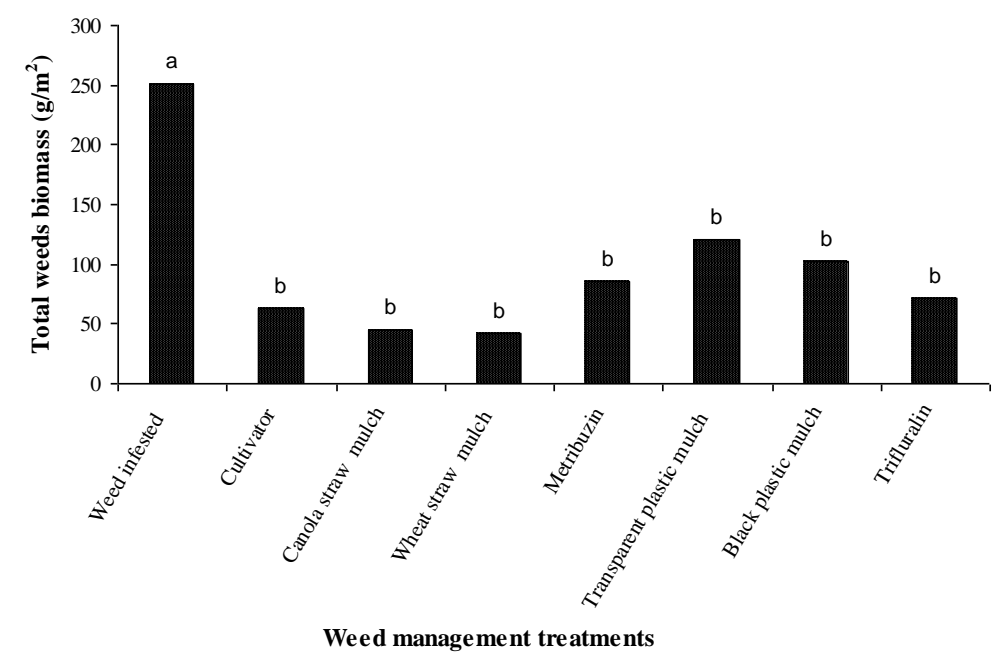

Figure 6. The effect of different weed management treatments on total weed biomass average $\left(\mathrm{g} / \mathrm{m}^{2}\right)$ in potato cultivation (The averages of at least one similar letter are not significantly different at $(\mathrm{P} \leq$ 0.05), using Duncan's multiple range test)

In present experiment, total weed biomass in the treatments of transparent and black plastics was 120.3 and $101.7 \mathrm{~g} / \mathrm{m}^{2}$, respectively, that showed the maximum biomass value comparing to the weed infested treatment (With biomass of $250.92 \mathrm{~g} / \mathrm{m}^{2}$ ) comparing to other treatments (Fig. 6), although the use of plastic mulches showed no significant difference with the use of herbicides and plant mulchs. However, the least amount of weed biomass was observed in treatments of wheat and canola mulches and it was found that these treatments can reduce weed biomass compared to weed infested treatment by a rate of $83 \%$ and $81 \%$ decrease, and this reflects the ability of plant residues in suppressing weeds and preventing their growth as well as preventing the spread of weeds and reducing the crop yield (Duppong et al., 2004). Plant residues are not only affect the soil but also can affect the germination, survival, growth and competitive ability of weed and crop plants (Majd et al., 2014; Pawlonka et al., 2015; Azadbakht et al., 2017). Although in current study, the lowest biomass of broadleaf and grass weeds showed a significant difference with the weed infested treatment and broadleaf weeds had more biomass than grass weeds (Fig. 7 and 8). Although, all chemical and ecological management treatments could statistically reduce broadleaf weed biomass compared to the weed infested treatment significantly, considering no significant difference between treatments of mulch and herbicides in terms of weeds biomass, it can be noted that the use of plant mulches could be more costly than the use of herbicides due to labor costs and costs related to mulch preparation. 


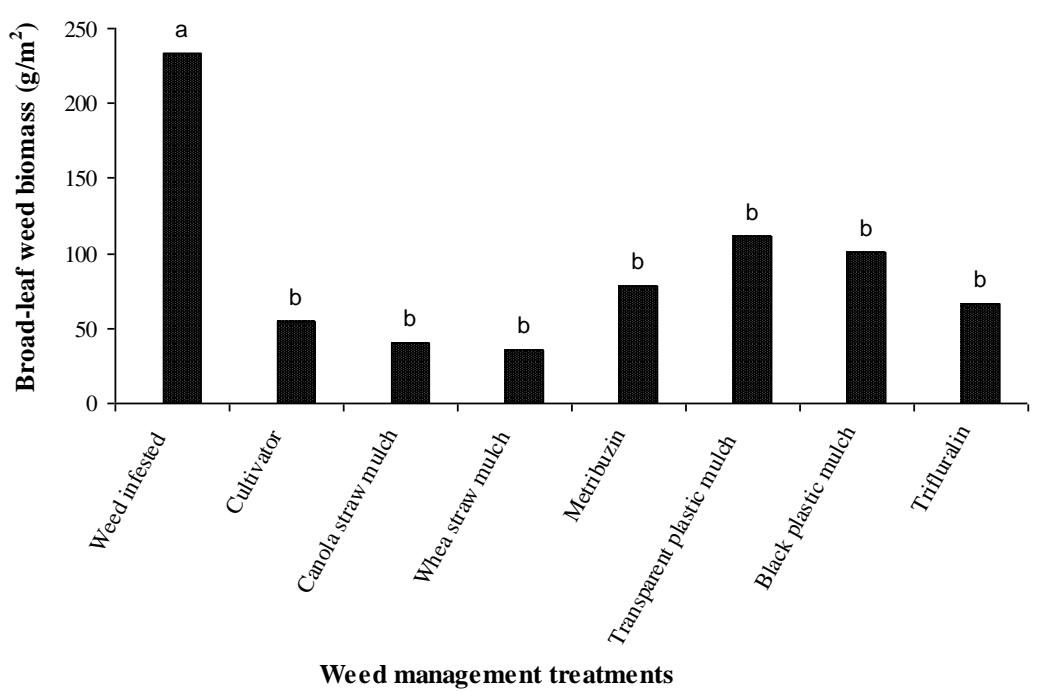

Figure 7. The effect of different weed management treatments on Broad-leaf weeds biomass average $\left(\mathrm{g} / \mathrm{m}^{2}\right)$ in potato cultivation (The averages of at least one similar letter are not significantly different at $(\mathrm{P} \leq 0.05)$, using Duncan's multiple range test)

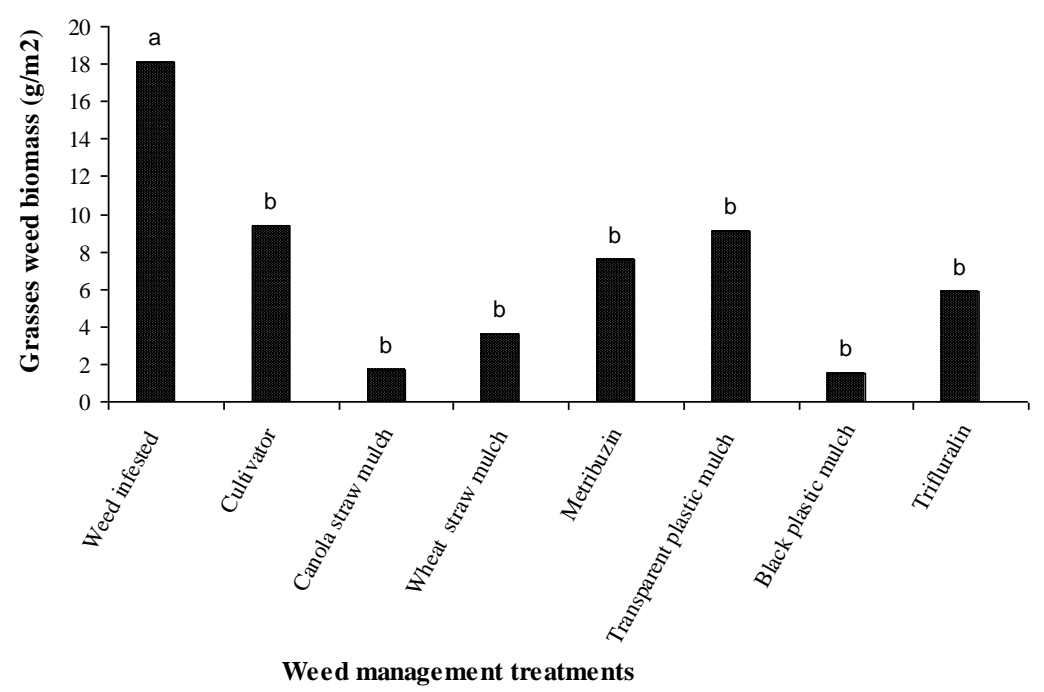

Figure 8. The effect of different weed management treatments on Grass weeds biomass average $\left(\mathrm{g} / \mathrm{m}^{2}\right)$ in potato cultivation (The averages of at least one similar letter are not significantly different at $(\mathrm{P} \leq 0.05)$, using Duncan's multiple range test $)$

\section{Potato tuber yield}

The potato yield was significantly affected $(\mathrm{P} \leq 0.01)$ by the applied treatments in the experiment (Table 3 and Fig. 9) except transparent plastic mulch treatment. 


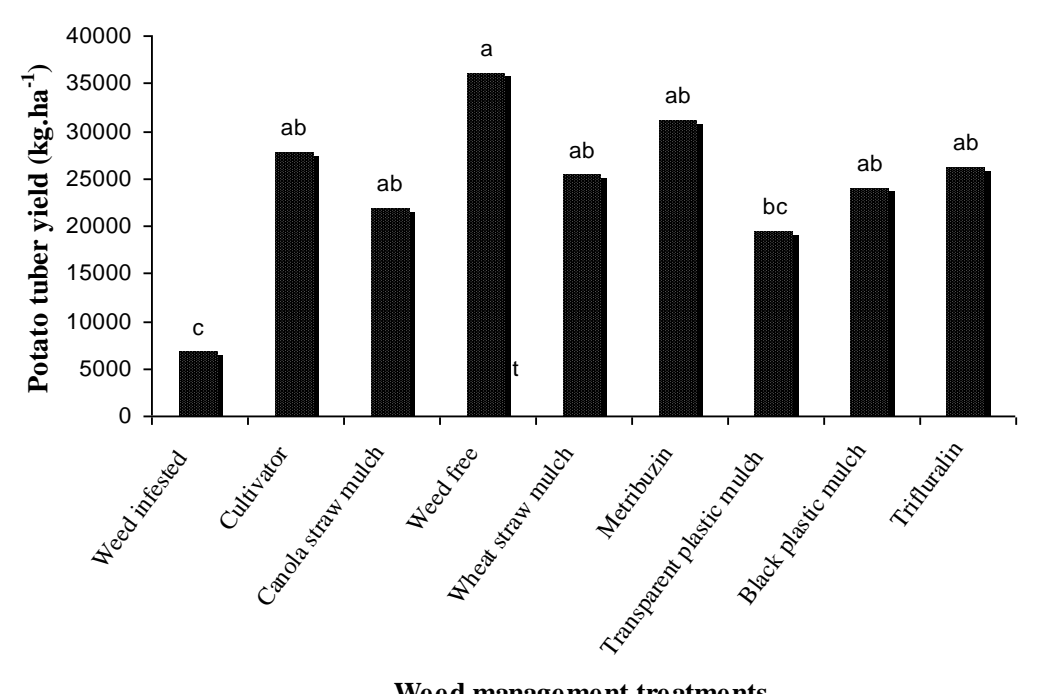

Weed management treatments

Figure 9. The effect of different weed management treatments on tuber yield ( $\left.\mathrm{kg}^{\mathrm{h}} \mathrm{ha} \mathrm{C}^{-1}\right)$ in potato cultivation (The averages of at least one similar letter are not significantly different at $(\mathrm{P} \leq 0.05)$, using Duncan's multiple range test)

In present experiment, the highest potato tuber yield was obtained at a rate of 36 ton/ha at weed free treatment that compared with the treatments of plant mulch, cultivator, herbicides and black plastic mulch were not significantly different but the transparent plastic mulch was significantly different compared to weed free treatment and transparent plastic mulch had the lowest tuber yield (19.3 ton/ha) after the weed infested treatment (6.6 ton/ha). The greatest reduction in tuber yield (about 83\%) was related to weed infested treatment and then transparent plastic mulch (about 47\%), and weed infested treatment was not significantly different with transparent plastic mulch treatment (Fig. 9), I seems that this is related to the lack of proper control of transparent plastic mulch to repress weeds in the experiment region in present study (Jafari et al., 2013; Majd et al., 2014).

Majd et al, (2014) applied also plastic mulch, herbicide and cultivator to control weeds and Mohammadduost Chamanabad et al, (2011) used herbal mulch, herbicide and cultivator to control weeds. However all control weed methods in present experiment were used simultaneously, so this experiment completes the results of others. In fact we were able to compare all the methods simultaneously and we developed other experiments mentioned above.

\section{Conclusion}

The use of non-chemical treatments of mulches and cultivator had a significant effect on potato weed density in both stations, so that the least amount of weed density was obtained by application of wheat straw mulch. However, the lowest weed biomass was observed in wheat and canola mulches treatments. It is also concluded that ecological treatments can control weeds as much as the herbicides. However, no significant difference between treatments of mulch and herbicides in terms of weeds biomass in present study, because 
mulches and cultivators can as well as herbicides prevent of germination, growth and development of weeds, both in the initial stage of weeds growth and in the subsequent stages, so it can be concluded that the use of mulches can be more costly than the use of herbicide due to labor costs and costs related to mulch preparation, By ignoring the cost, it can be noted that the ecological methods such as application of plant residues can be more environmental friendly. The presence of herbicides in the ecosystem is harmful for health humans and animals.

\section{REFERENCES}

[1] Azad, B, Hassandokht, M. R., Parvizi K. (2015): Effect of mulch on some characteristics of potato in Asadabad, Hamedan, Iran. - International Journal of Agronomy and Agricultural Reserch 6(3): 139-147.

[2] Azadbakht, A., Alebrahim, M. T., Mohammadduost Chamanabad, H. R., Ghavidel, A., Karbalaei Khiavi, H. (2017): The effect of chemical and non-chemical weed management methods on chemical and biological properties of soil in potato cultivation in Ardabil province. Iran. - Applied Ecology and Environmental Research 15(3): 771-783.

[3] Blackwell, G. (2011): Abundance and diversity of herbaceous weeds in sheep/beef pastures, South Island, New Zealand. - New Zealand Journal of Agricultural Research 54 (1): 53-69.

[4] Borzouei M., Izadi E., Rashed Mohassel M. H, Hassanzadeh M., Rastgoo, M. (2013): Effect of Trifluralin herbicide residues in soil on the growth of some plants. - The 4th Iranian Weed Conference. 6-8 Feb. (2013): Ahvaz University. (In Persian with English abstract).

[5] Channappaguar, B. B., Biradar, N. R., Bharmagoudar, T. D., Koti, R. V. (2007): Crop-weed competition and chemical control of weeds in potato. - Karnataka J. Agricaltioral Science 20:715-718.

[6] Channappaguar, B. B., Biradar, N. R., Bharmagoudar, T. D., Koti, R. V. (2007): Crop-weed competition and chemical control of weeds in potato. - Karnataka Journal. Agriculture Science 20: 715-718.

[7] Dejam, M., Ebadi pour, A. R., Pourazar, R., Muhtasebi, M. (2010): Effect of mechanical (weeding) and chemical control on yield of onion cultivars. - Journal of weeds ecology 1: 3140.

[8] Dhima, K. V., Vasilakoglou, I. B., Eleftherohorinos, I. G., lithourgidis, A. S. (2006): Allelopathic potential of winter cereal cover crop mulches on grass weed suppression and sugar beet development. - Crop Science 46: 345-352.

[9] Didon, U. M. E., Kolseth. A. K., Widmark, D., Persson, P. (2014): Cover Crop Residues Effects on Germination and Early Growth of Annual Weeds. - Weed science 62(2): 294-302.

[10] Duppong, L. M., Delate, K., Liebmen, M., Horton, R., Kraus, G., Petrich, J., Chowdbury, P. K. (2004): The effect of natural mulches on crop performance, weed suppression and biochemical constituents of catnip and St. Johns Wort. - Crop Science 44: 861-869.

[11] Dvorak, P. J., Tomasek, P., Kuchtova, K., Hamouz, J., Hajslova, D., Schulzova, V. (2012): Effect of mulching materials on potato production in different soil climatic conditions. Romanian Agricalture Reserch 29: 201-209.

[12] Haidar, M. A., Sidahmed, M. M. (2000): Soil solarization and chicken manure for the control of Orobanche crenata and other weeds in Lebanon. - Crop Protection 19: 169-173.

[13] Hutchinson, P., Beutler, B., Farr, J. (2011). Hairy nightshade (Solanum sarrachoides) competitionwith two potato varieties. - Weed Science 59: 37-42. 
[14] Jafari, R., Veisanlo, F., Javan, R. (2013): Weeds associated with potato (Solanum tuberosum) crops. - International Journal of Agriculture and Crop Sciences 6 (20): 1403-1406.

[15] Judice, W. E., Griffin, J. L., Etheredge, L. M., Jones, C. A. (2007): Effects of crop residue management and tillage on weed control and sugarcane production. - Weed Technology 21: 606-611.

[16] Kunz, C., Weber, J. F., Gerhards, R. (2015): Benefits of Precision Farming Technologies for Mechanical Weed Control in Soybean and Sugar Beet-Comparison of Precision Hoeing with Conventional Mechanical Weed Control. - Agronomy 5(2): 130-142.

[17] Lososova, Z., Chytry, M., Kuhn, I. (2008): Plant attributes determining the regional abundance of weeds on central European arable land. - Journal of Biogeography 35: 177187.

[18] Majd, R., Mohammaddust Chamanabad, H. R., Alebrahim, M. T., Nateghi, G. A. (2014): The evaluation of solarization efficacy with polyethylene sheet mixed with chemical and physical treatments for weeds control and potato (Solanum tuberosum) yield. - Research In Crop Ecosystem 1(2): 33-43. (In Persian with English abstract).

[19] Maldonado, J. A., Osornio, J. J., Barragan. A. T., Anaya, A. L. (2001): The use of allelopathic legume cover and mulch species for weed control in cropping systems. Agronomy Journal 93: 27-36.

[20] Mohammadduost Chamanabad, H. R., Asghari1, A., Habibi, G. h. R., Pourmorad. K. B. (2011): Effect of herbicides and crop residue on integrated weed control in potato. Electronic Journal of Crop Production 4 (1): 171-185.

[21] Najafi, H., Hasanzadeh, M., Rashaed Mohasel, M. H., Zand, E., Baghestani, M. A. (2016): Ecological management of agricultural weeds. - Iranian Plant Protection Research Institute, 559-565.

[22] Nikolic, L., Ilic, O., Dzigurski, D., Ljevnaic-Masic, B. (2013): Analysis of weed flora in conventional and organic potato production. - Biologica Nyssana 4 (1-2): 9-14.

[23] Pawlonka, Z., Rymuza, K., Starczewski, K., Bombik, A. (2015): Biodiversity of Segetal weed community in continuous potato cultivated with Metribuzin-based weed control. JOPPR 55 (1): 53-58.

[24] Rashed Mohassel, M. H., Naajafi, H., Akbarzadeh, M. D. (2001): Weed Biology \& Control. Ferdowsi University publications, Mashhad, Iran, 404.

[25] Shannon, C. E., Wiener, W. (1949): The Mathematical Theory of Communication. University of Ilinois Press, Urbana.

[26] Sheikhi-Gorjan, A., Najafi, H., Abbassi, S., Saber, F., Rashid, M. (2012): A guideline for pesticides in Iran. - Payetakht book publication, 395.

[27] Shiyam, J. O., Obiefuna, J. C., Ofoh, M. C., Oko, B. F. D. (2011): Effect of Sawdust Mulch and Fertilizer on Weed Flora Composition and Growth in Plantain/Cocoyam Intercrop in the Nigerian Rainforest Zone. - World Journal of Agricultural Sciences 7(5): 629-632.

[28] Weber, J. F., Kunz, C. H., Gerhards, R. (2016): Chemical and mechanical weed control in soybean (Glycine max). - University of Hohenheim, Institute of Phytomedicine, Otto-SanderStrabe 5, 70599 Stuttgart, Germany, 171-176.

[29] Zaki, M. M., Saleh, E. A., Mohamed Sonya, H., Rahal, A., Sadik, A. S. (2014): Persistence of Sencor herbicide in Streptomycetes-inoculated soil and its effect on some microbial soil. Int.J.Curr. Microbiology App. Science 3(3): 726-738.

[30] Zand, E., Baghestani, M. A., Bitarafan, A., Shimi, P. (2007): A guidline for herbicides in Iran. - Jihad Daneshgahi Mashhad publications.

[31] Zhang, F., Li, M., Qi, J., Li, F., Sun, G. (2015): Plastic Film Mulching Increases Soil Respiration in Ridge-furrow Maize Management. - Arid Land Research and Management. 29(4): 432-453. 